\title{
Interseismic Deformation and Earthquake Hazard along the Southernmost Longitudinal Valley Fault, Eastern Taiwan
}

\author{
by Ray Y. Chuang*, M. Meghan Miller, Yue-Gau Chen, Horng-Yue Chen, J. Bruce H. Shyu, \\ Shui-Beih Yu, Charles M. Rubin, Kerry Sieh, and Ling-Ho Chung
}

\begin{abstract}
About half of the $8 \mathrm{~cm} / \mathrm{yr}$ of oblique convergence across the active convergent plate boundaries of Taiwan occurs in eastern Taiwan, across the Longitudinal Valley. Significant shortening and left-lateral slip occurs across the Longitudinal Valley fault there, both as shallow fault creep and as seismogenic fault slip. The southernmost Longitudinal Valley fault comprises an eastern Peinan strand and a western Luyeh strand. We derive an interseismic block model for these two strands using data from a small-aperture Global Positioning System (GPS) campaign and leveling. The model provides estimates of fault slip rates and quantifies slip partitioning between the two strands. A $45 \mathrm{~mm} / \mathrm{yr}$ dip-slip rate on the northern Peinan strand diminishes southward, whereas the left-lateral component increases. In contrast, nearly pure dip-slip motion of about $20 \mathrm{~mm} / \mathrm{yr}$ on the southern Luyeh strand diminishes northward to about $8 \mathrm{~mm} / \mathrm{yr}$ and picks up a component of left-lateral motion of about $15 \mathrm{~mm} / \mathrm{yr}$ before it dies out altogether at its northern terminus. The Luyeh and the northern Peinan strands record near-surface creep, but the southern Peinan strand appears locked. The potential earthquake magnitude for the two strands may be as high as $M_{\mathrm{w}} 6.5$. We anticipate seismic rupture mainly on the locked portion of the Peinan strand.
\end{abstract}

\section{Introduction}

Arc-continent collision figures prominently in the tectonic development of Taiwan. Based on the studies of the tectonic evolution of Taiwan (e.g., Shyu, Sieh, and Chen, 2005), the Longitudinal Valley marks a suture zone between the Central Range block and the volcanic arc, with spectacular geologic evidence for shortening resulting from rapid convergence in eastern Taiwan (Fig. 1). Currently, the main active structure of the Longitudinal Valley is the steeply east-dipping Longitudinal Valley fault (Fig. 2), which accounts for about $30-40 \mathrm{~mm} / \mathrm{yr}$ of present-day convergence (Yu et al., 1997). The fault is experiencing high rates of sinistral-reverse motion along its middle and southern extent, and predominantly sinistral motion in the north (Yu and Liu, 1989). The fault zone displays both creeping and locked segments and has produced moderate destructive earthquakes. In 1951 rupture of more than $75 \mathrm{~km}$ of the north and central portions of the fault generated three such (e.g., Shyu et al., 2007; Fig. 2). More recently, the December $2003 M_{\mathrm{w}} 6.8$ Chengkung earthquake accompanied $13 \mathrm{~mm}$ of horizontal and $26 \mathrm{~mm}$ of vertical surface deformation (Chen et al., 2005). However, large earthquakes and obvious surface rupture haves been absent along the southernmost part of the Longitudinal Valley fault. Recent investigations by Shyu et al. (2008) also document activity on

\footnotetext{
* Now at Indiana University, Bloomington, Indiana.
}

the eastern flank of the Central Range along the Central Range fault, a second major structure (Fig. 2).

In order to characterize aseismic and seismic deformation and to illustrate earthquake hazards better, we established a dense GPS campaign network in the Luyeh area, used a colocated local leveling survey (Yu and Kuo, 2001), and conducted detailed local geologic mapping (Shyu et al., 2002; Shyu et al., 2008). This study presents and models the GPS and leveling data in a manner that is consistent with the geologic studies (e.g., Shyu et al., 2002; Shyu et al., 2008).

The southern segment of the Longitudinal Valley fault outcrops mostly along the western flank of the Coastal Range. Around Luyeh, however, the fault bifurcates into the Luyeh strand on the west and the Peinan strand on the east (Lee et al., 1998; Shyu et al., 2002; Shyu et al., 2008; Fig. 3). Between these two strands are two tablelands, Kaotai on the north and Peinanshan on the south (Fig. 3). The local active tectonic setting of the area is further complicated by the possibility of a west-dipping blind Central Range fault south of Chihshang (Shyu et al., 2006).

\section{GPS Observations}

Building on an existing network of GPS stations near Luyeh (Yu and Kuo, 2001) in the southern Longitudinal 


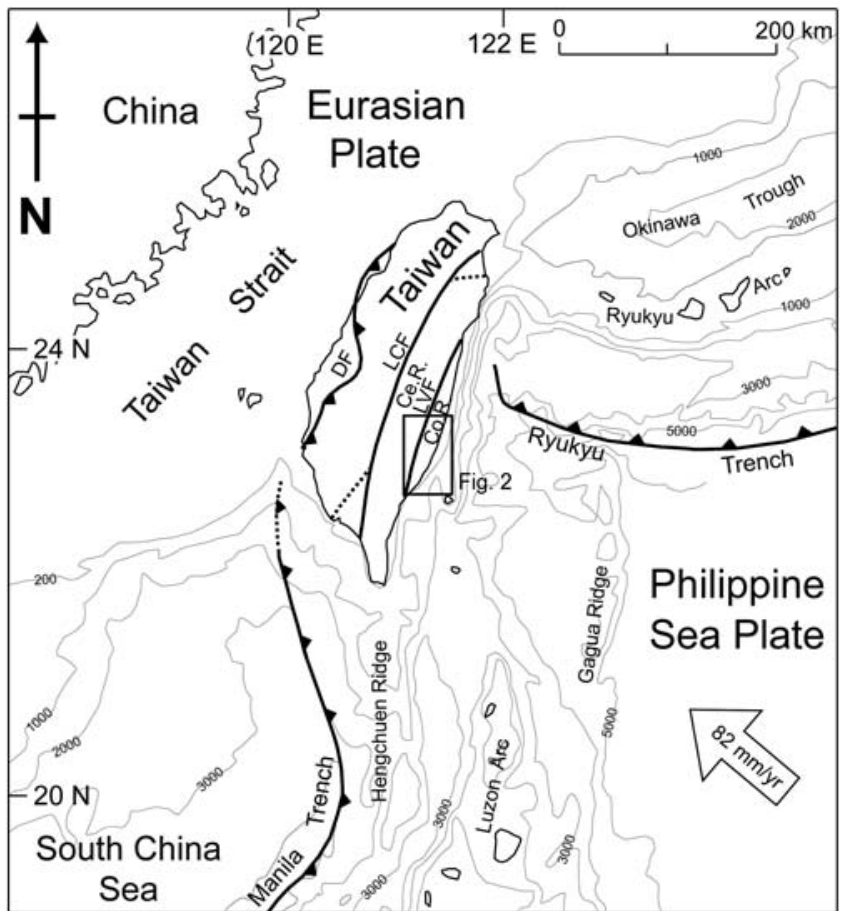

Figure 1. Tectonic setting of Taiwan. The Philippine Sea plate subducts northwestward beneath the Eurasian plate along the Ryukyu trench at the latitude of about $24^{\circ} \mathrm{N}$. To the south, oceanic lithosphere of the South China Sea subducts beneath the Philippine Sea plate along the Manila trench. Back-arc spreading of the Okinawa trough extends westward into northeastern Taiwan. The Longitudinal Valley fault (LVF) is the dominant structure in the Longitudinal Valley, eastern Taiwan. Philippine Sea-Eurasia plate convergence of $82 \mathrm{~mm} / \mathrm{yr}$ is from Yu et al. (1997). The Central Range (CeR), Coastal Range (CoR), deformation front (DF), and LishanChaochou fault (LCF) are indicated.

Valley, we added 20 new stations to expand the network across the Luyeh and Peinan fault strands around the northern Peinanshan, Lungtien, Yongan, and Rueiyuan (Fig. 4a).

Since 2001, we have occupied the GPS network annually for 5 days in November in order to avoid strong summer climate effects. We added fiducial control by including data from continuously recording GPS sites operated by the Institute of Earth Sciences, Academia Sinica (IESAS), the Central Weather Bureau, and the Ministry of the Interior, Taiwan. The 2003 Chengkung earthquake interrupted interseismic deformation. Fault rupture generated coseismic displacement and larger postseismic displacement, as documented by continuous GPS observations (Chen et al., 2005; Lee et al., 2006). The earthquake illuminated the location and orientation of regional faults (Lee et al., 2006; Hsu et al., 2009). For this study, GPS data from 2001 to 2003 were used to characterize interseismic strain partitioning and accumulation.

For each campaign, we occupied 8-12 stations simultaneously for 7-14 hr, at a sampling rate of $15 \mathrm{~s}$ and a horizon cutoff angle of $10^{\circ}$. We removed environmental obstructions such as trees or grass in the field to the extent possible, to reduce the effects of multipath. We converted the raw data

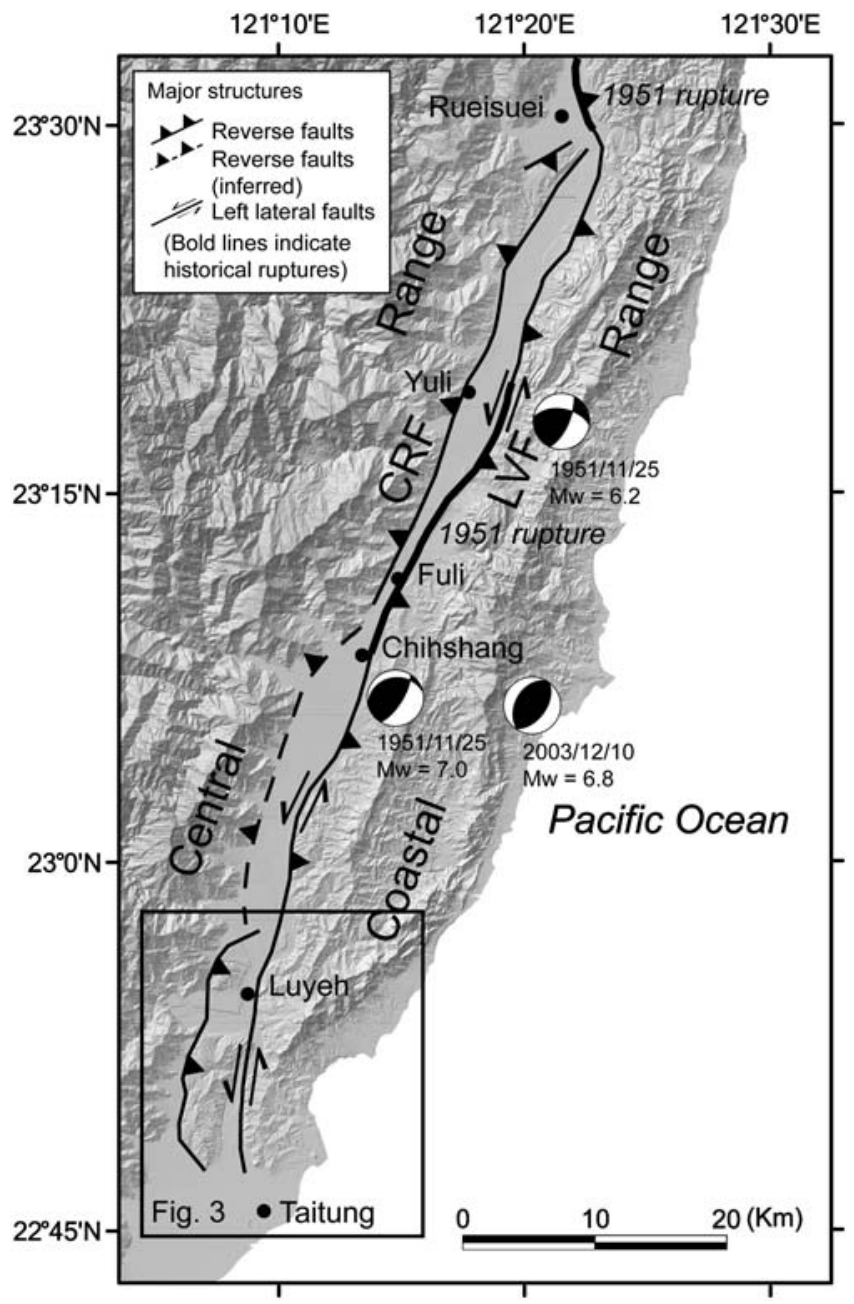

Figure 2. Major active structures of the southern Longitudinal Valley, modified from Shyu, Sieh, Chen, et al. (2005). Two main shocks of the 1951 earthquake series occurred in November (Cheng et al., 1996) with successive moment magnitudes $M_{\mathrm{w}} 7.0$ and $M_{\mathrm{w}}$ 6.2. The 1951 earthquakes ruptured the Longitudinal Valley fault around Rueisuei and from Yuli to Chihshang (Shyu et al., 2007). The $2003 M_{\mathrm{w}} 6.8$ Chengkung earthquake occurred at a depth of $16 \mathrm{~km}$ (Kuochen et al., 2006). The Central Range fault (CRF) and Longitudinal Valley fault (LVF) are indicated.

to Receiver Independent Exchange (RINEX) format for postprocessing. For the continuously recording GPS sites, the receiver sample setting was the same as for the campaign receiver, except the data logging was in $30 \mathrm{~s}$ and $1 \mathrm{~Hz}$, and the time span was $24 \mathrm{hr}$ a day. We processed all GPS data into daily solutions following the standard procedures of the Bernese V4.2 software (Hugentobler et al., 2001) as baselines relative to the reference station $\mathrm{S} 105$, which has been recording continuously in the Central Range since 1994. For the field campaigns, we combined daily solutions into a session solution, which we linked to the International Terrestrial Reference Frame 2000 (ITRF2000) by inclusion of station S01R at Penghu on the Chinese continental margin.

During the IESAS data processing, we employed the International GPS Service final orbit solution in order to reduce 


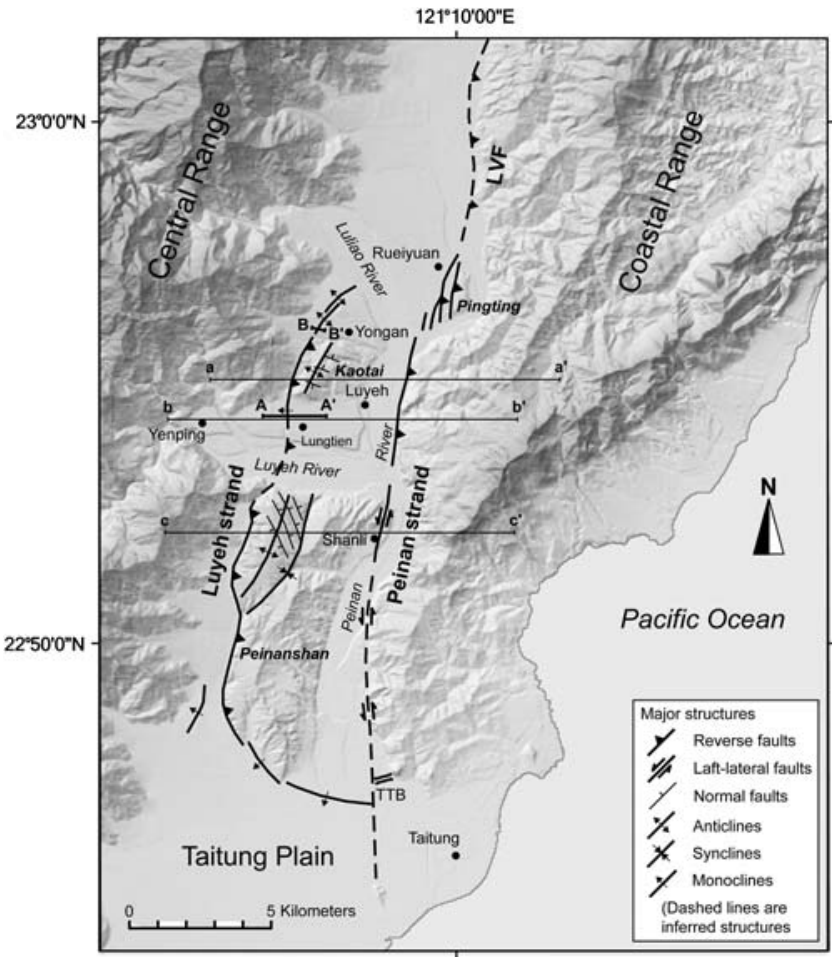

Figure 3. Active faults of the Luyeh area, modified from Shyu et al. (2008). South of Rueiyuan, deformation is accommodated by the Luyeh and Peinan strands of the Longitudinal Valley fault. In the northern Peinanshan, the anticline-syncline pair represents faultrelated folding above the Luyeh fault. The locations of topographic profiles $\mathrm{AA}^{\prime}$ and $\mathrm{BB}^{\prime}$ (Fig. 4) and tectonic east-west cross sections $\mathrm{aa}^{\prime}, \mathrm{bb}^{\prime}$, and $\mathrm{cc}^{\prime}$ (Figs. 8 and 10) are shown. The Taitung Bridge is indicated by TTB.

the effects of the orbit uncertainty. Use of the antenna calibration table from the Astronomical Institute University of Bern, National Geodetic Survey and National Oceanic and Atmospheric Administration, U.S. Department of Commerce reduced the effect of the phase center biases. The doubledifferenced ionosphere-free linear combination of carrier phase observations mitigates the first-order ionospheric bias. We estimated the difference between the actual and model zenith delay based on a standard atmosphere model (Saastamoinen, 1973). In order to determine the residual tropospheric zenith delay, we conducted simultaneous two-hour estimates of position and atmospheric delay by least squares adjustment. We constrained the daily position of the Paisha station (S01R) at Penghu, which is located in the Chinese continental margin, to precise ITRF2000 coordinates. We combined daily solutions into a session solution for the campaign observations. We generated the daily solution or session solution in software independent exchange format.

The one-sigma error values of the semimajor and semiminor axes for the horizontal components represent 2-4 mm accuracy for campaign stations and less than $1 \mathrm{~mm}$ for continuously recording stations. These values are more than adequate for detecting crustal deformation in the southern Longitudinal Valley. In contrast, the uncertainties of about
$9 \mathrm{~mm}$ for measurements of vertical deformation do not provide results that are adequately precsie for detecting vertical crustal deformation.

The GPS results show large discontinuities in relative velocity across the Luyeh and Peinan strands (Fig. 4a; Table 1), consistent with preliminary results of Yu and Kuo (2001). The far-field stations along the eastern coast show average velocities of about $34.2 \mathrm{~mm} / \mathrm{yr}$ along an azimuth of $321^{\circ}$. From south to north, the azimuth of relative velocities become progressively more northerly. Stations in the Central Range show only small velocities of a few millimeters per year. Around site ERPN, the Longitudinal Valley fault has several closely spaced branches (Fig. 4b), and velocities across these faults reveal clear gradients. For example, a large velocity discrepancy of about $16.9 \mathrm{~mm} / \mathrm{yr}$ between stations ERPN and 0308 can be due to shallow slip on two major faults around Rueiyuan (Fig. 4b). Peculiarly, campaign station S128 shows a different velocity orientation than adjacent sites. A similar velocity has also been observed in previous GPS results from 1997 to 1999 (Yu and Kuo, 2001).

A few kilometers further south, stations show large velocity gradients but similar northeast azimuths (e.g., 8050 and S072, and S199 and S126). Near the northeastern tip of the Peinanshan, stations S212 and S217 form a short baseline spanning the Longitudinal Valley fault that shows no appreciable shortening in length or change in azimuth. Stations farther west in this group display a counterclockwise fanning of GPS velocities and a westward decrease in values between stations S218 and S215. Further south, stations 0207 and 0206 show an obvious $62^{\circ}$ difference in azimuth, indicating strong left-lateral movement of the Peinan strand, consistent with previous observations (Yu et al., 1992; Lee et al., 1998). Stations S203 and S201, on the Lungtien Surface, show a similar difference in azimuth across the Luyeh strand and a $5.5 \mathrm{~mm} / \mathrm{yr}$ difference in velocity across the Luyeh strand. The $92^{\circ}$ difference in azimuth between stations S203 and S204 nearby is odd. To the south, velocities of stations S211 and S215 differ by about $10.9 \mathrm{~mm} / \mathrm{yr}$ and $53^{\circ}$. Consequently, the Luyeh strand shows thrust-dominant motion with little left-lateral motion to the south and stronger leftlateral motion to the north. In contrast, the Peinan strand shows thrust movement to the north and left-lateral strikeslip motion to the south.

\section{Other Geodetic Data}

\section{Leveling Data}

Precise leveling data constrain active deformation near Lungtien better than the GPS data, because the latter display large uncertainties in the vertical component (Figs. 4c, 5). We used a high-precision level and two invar rods that diminish the effects of thermal expansion for the leveling surveying. The leveling followed the United States first-order class I geodetic leveling procedure (Schomaker and Berry, 1981), executed strictly by double-run difference tolerances in a 
(a)

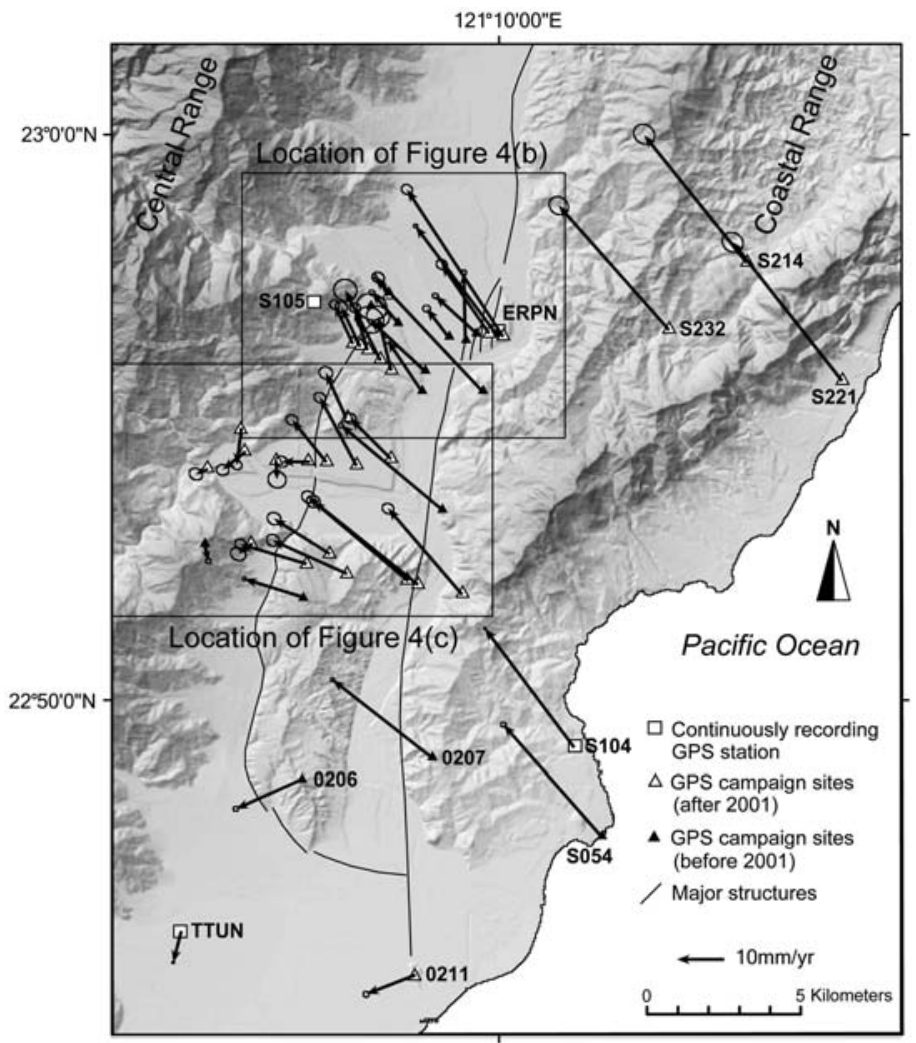

(b)

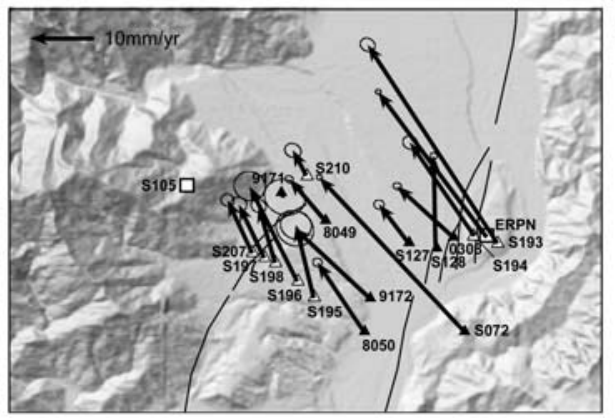

(c)

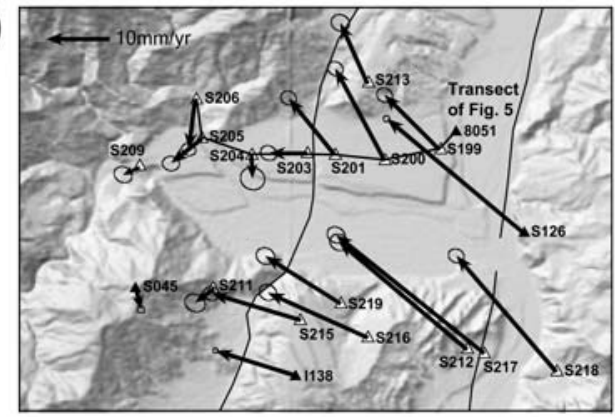

Figure 4. (a) The GPS velocity field in the Luyeh area from 2001 to 2003. The white squares are continuously recording GPS stations. The black triangles are GPS campaign sites installed before 2001. The white triangles are GPS campaign sites installed and occupied after 2001. Velocities are shown relative to station S105 in the Central Range. Uncertainty ellipses represent $95 \%$ confidence intervals. The areas included in (b) and (c) are indicated by the insets. (b) GPS velocities around the Kaotai and Rueiyuan areas. (c) GPS velocities around the Lungtien and northern Peinanshan areas. The transect from 8051 to S206 shows the location of the leveling profile in Figure 5. Leveling site 8051 was not occupied by a GPS.

single section, using instruments that are regularly checked and carefully calibrated before every survey. Differencing automatically recorded heights on two rods from a single position determined the differences in elevation. We confirmed that the line of sight through the central axis of the telescope of the level was constant, the rods stood vertically, and the points where the rods stood were stable. We carefully corrected systematic errors, such as collimation errors, refraction error, and thermal extension.

The April 2002 precise leveling line followed a major east-west road on the Lungtien surface (Fig. 4c), which is an 3000-yr-old river terrace (Shyu et al., 2008). We established a scond baseline along a major road from the Yongan area to the Rueiyuan area in April 2003. Because the deformation produced by the 2003 Chengkung earthquake affected the leveling results, we used only the Lungtien leveling data in this study. Because the Lungtien leveling route is short and is not tied to any tide gauge, we referenced elevations to site S206, which is located closer to the Central Range, and calculated cumulative elevation changes with respect to S206. Our results show that S201 rose relative to S203 at a rate of about $6 \mathrm{~mm} / \mathrm{yr}$. These stations are atop and at the base of a monoclinal warp associated with the eastdipping Luyeh thrust fault. The leveling profile shows that the surface tilted eastward between surveys, such that the rate of uplift of station $8051,3 \mathrm{~km}$ farther east, is no greater than 
Table 1

GPS Velocity Field in the Luyeh Area

\begin{tabular}{|c|c|c|c|c|c|c|c|c|c|}
\hline Station & Long. $\left({ }^{\circ} \mathrm{E}\right)$ & Lat. $\left({ }^{\circ} \mathrm{N}\right)$ & $V_{N}(\mathrm{~mm} / \mathrm{yr})$ & $V_{E}(\mathrm{~mm} / \mathrm{yr})$ & $V(\mathrm{~mm} / \mathrm{yr})$ & Azi $\left({ }^{\circ}\right)$ & $A(\mathrm{~mm} / \mathrm{yr})$ & $b(\mathrm{~mm} / \mathrm{yr})$ & $\theta\left({ }^{\circ}\right)$ \\
\hline 0206 & 121.109 & 22.809 & -6.3 & -14.1 & 15.4 & 246 & 0.8 & 0.8 & 154 \\
\hline 0207 & 121.147 & 22.817 & 16.6 & -21.2 & 26.9 & 308 & 0.6 & 0.6 & 154 \\
\hline 0211 & 121.142 & 22.753 & -4.1 & -10.5 & 11.3 & 249 & 1.0 & 0.9 & 151 \\
\hline 0308 & 121.160 & 22.942 & 7.9 & -8.7 & 11.7 & 312 & 1.0 & 0.8 & 157 \\
\hline 8049 & 121.137 & 22.945 & 6.4 & -5.5 & 8.4 & 320 & 1.0 & 0.8 & 155 \\
\hline 8050 & 121.144 & 22.925 & 10.9 & -7.3 & 13.1 & 326 & 1.1 & 1.0 & 167 \\
\hline 9171 & 121.129 & 22.950 & -0.4 & 0.7 & 0.8 & 118 & 4.9 & 4.1 & 158 \\
\hline 9172 & 121.145 & 22.931 & 10.9 & -11.7 & 16.0 & 313 & 4.6 & 4.0 & 146 \\
\hline ERPN & 121.166 & 22.942 & 22.9 & -17.1 & 28.6 & 307 & 0.6 & 0.6 & 160 \\
\hline I138 & 121.109 & 22.864 & 3.9 & -12.6 & 13.2 & 287 & 0.6 & 0.6 & 156 \\
\hline S045 & 121.080 & 22.880 & -3.7 & 0.8 & 3.8 & 168 & 0.9 & 0.8 & 155 \\
\hline S054 & 121.197 & 22.794 & 23.6 & -20.8 & 31.4 & 319 & 0.9 & 0.8 & 154 \\
\hline S072 & 121.162 & 22.925 & 24.4 & -22.9 & 33.5 & 317 & 0.7 & 0.6 & 153 \\
\hline S104 & 121.189 & 22.820 & 25.3 & -19.0 & 31.6 & 323 & 0.3 & 0.3 & 170 \\
\hline S105 & 121.112 & 22.951 & 0.0 & 0.0 & 0.0 & 0 & 0.0 & 0.0 & $\mathbf{0}$ \\
\hline S126 & 121.150 & 22.890 & 18.0 & -21.5 & 28.1 & 310 & 0.8 & 0.7 & 160 \\
\hline S127 & 121.152 & 22.941 & 6.0 & -4.6 & 7.6 & 322 & 1.2 & 1.1 & 169 \\
\hline S128 & 121.157 & 22.940 & 14.5 & -0.3 & 14.5 & 359 & 0.8 & 0.8 & 156 \\
\hline S193 & 121.168 & 22.941 & 31.4 & -20.5 & 37.5 & 327 & 1.8 & 1.5 & 155 \\
\hline S194 & 121.164 & 22.942 & 14.7 & -10.1 & 17.9 & 325 & 1.8 & 1.5 & 154 \\
\hline S195 & 121.135 & 22.931 & 11.5 & -2.8 & 11.9 & 347 & 3.7 & 3.3 & 160 \\
\hline S196 & 121.132 & 22.934 & 15.0 & -7.5 & 16.7 & 333 & 3.7 & 3.4 & 163 \\
\hline S197 & 121.128 & 22.937 & 9.0 & -2.6 & 9.3 & 344 & 1.8 & 1.5 & 153 \\
\hline S198 & 121.126 & 22.938 & 8.4 & -4.0 & 9.3 & 335 & 1.9 & 1.7 & 153 \\
\hline S199 & 121.135 & 22.905 & 8.7 & -8.7 & 12.3 & 315 & 1.9 & 1.6 & 154 \\
\hline S200 & 121.125 & 22.903 & 14.6 & -7.8 & 16.5 & 332 & 1.9 & 1.6 & 151 \\
\hline S201 & 121.116 & 22.904 & 9.0 & -7.3 & 11.6 & 321 & 1.9 & 1.6 & 152 \\
\hline S203 & 121.111 & 22.904 & 0.0 & -6.1 & 6.1 & 270 & 2.0 & 1.7 & 151 \\
\hline S204 & 121.101 & 22.904 & -3.9 & 0.2 & 3.9 & 178 & 2.9 & 2.6 & 160 \\
\hline S205 & 121.092 & 22.907 & -3.9 & -4.9 & 6.2 & 231 & 2.0 & 1.7 & 171 \\
\hline S206 & 121.091 & 22.914 & -7.9 & -1.0 & 7.9 & 187 & 1.7 & 1.4 & 158 \\
\hline S207 & 121.124 & 22.939 & 8.4 & -3.9 & 9.2 & 335 & 1.6 & 1.4 & 157 \\
\hline S209 & 121.081 & 22.902 & -1.2 & -2.6 & 2.9 & 245 & 2.2 & 1.8 & 154 \\
\hline S210 & 121.134 & 22.953 & 4.0 & -2.1 & 4.5 & 332 & 2.0 & 1.6 & 156 \\
\hline $\mathrm{S} 211$ & 121.094 & 22.880 & -2.2 & -3.0 & 3.8 & 234 & 2.5 & 2.0 & 154 \\
\hline $\mathrm{S} 212$ & 121.140 & 22.869 & 17.0 & -20.2 & 26.4 & 310 & 2.2 & 1.9 & 153 \\
\hline S213 & 121.122 & 22.917 & 9.6 & -4.3 & 10.5 & 336 & 2.2 & 1.9 & 156 \\
\hline S215 & 121.110 & 22.874 & 4.2 & -14.1 & 14.7 & 287 & 1.8 & 1.6 & 152 \\
\hline S216 & 121.122 & 22.871 & 7.1 & -15.8 & 17.3 & 294 & 2.1 & 1.8 & 154 \\
\hline S217 & 121.143 & 22.868 & 18.7 & -23.4 & 30.0 & 309 & 2.2 & 1.8 & 154 \\
\hline S218 & 121.156 & 22.865 & 18.4 & -15.8 & 24.3 & 319 & 1.9 & 1.6 & 159 \\
\hline S219 & 121.117 & 22.877 & 7.5 & -11.9 & 14.0 & 302 & 2.2 & 1.9 & 155 \\
\hline S221 & 121.268 & 22.928 & 29.6 & -23.3 & 37.7 & 322 & 3.5 & 3.0 & 146 \\
\hline $\mathrm{S} 232$ & 121.217 & 22.943 & 26.5 & -23.5 & 35.4 & 318 & 3.2 & 2.7 & 146 \\
\hline TTUN & 121.073 & 22.766 & -6.7 & -1.7 & 6.9 & 194 & 0.4 & 0.3 & 163 \\
\hline
\end{tabular}

All stations including continuously recording stations (in bold) and campaign stations are with respect to S105. Explanations of the column headers are as follows: Lon, longitude; Lat, latitude; $V$, velocity; $V_{N}$, velocity in the north component; $V_{E}$, velocity in the east component; Azi, azimuth; A, major axis of the error ellipse; $b$, minor axis of the error ellipse; and $\theta$, azimuth of major axis of error ellipse.

that of S203 (Fig. 5). The $6 \mathrm{~mm} / \mathrm{yr}$ uplift rate across the monocline and the steep tilt indicate that the Luyeh strand is creeping very near the surface, and that the geometry of the Luyeh fault may be curved in the upper few kilometers.

\section{Fault-Scarp Surveying}

The Luyeh fault disrupts the tread of the Lungtien terrace (Fig. 3). In order to estimate long-term deformation, we produced a detailed topographic profile along the Lungtien surface using a laser-ranging total station (Fig. 6a), tying all conventional survey points to GPS site S203. The profile clearly shows an 11-m-high monoclinal scarp across the Luyeh fault, possibly modified by younger fluvial or alluvial sedimentation on the foot-wall block. About $500 \mathrm{~m}$ to the west of the monoclinal scarp is a gentle, 4-m-high scarp that may result from either fluvial processes or active faulting. If the scarp represents unmodified offset of an active fault, 


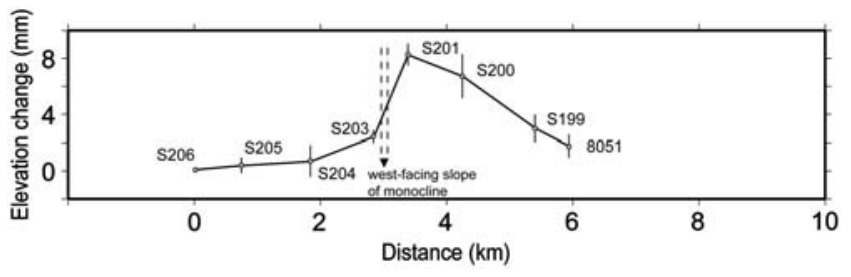

Figure 5. Leveling profile of the Lungtien surface across the Luyeh strand. The leveling route is shown in Figure 4b. The observation period is from April 2002 to April 2003. Elevation changes are referenced to site S206, located on the relatively stable Central Range block. Uncertainties are one standard deviation.

it records a minor west-side-up splay of the Central Range fault. To the north, a topographic profile on the Yongan alluvial fan (Fig. 3, 6b) exhibits fault-related folding and suggests that motion across the Luyeh decreases to the north as a concealed thrust fault.

\section{Constraints and Modeling}

We have derived a kinematically consistent block model that estimates block motions and fault slip rates, characterizing the contributions of interseismic coupling and partitioned fault slip to the geodetically determined deformation rates. Each block is considered to be a rigid body and only deforms on its edges due to elastic-strain accumulation on boundary faults. We inverted 27 horizontal GPS velocity determinations to estimate motion of three blocks relative to a fixed block. The blocks are bounded by known faults using a priori constraints on the fault geometry and locking.

\section{Block Model}

Geologic constraints governed the choice of three major model fault blocks, separated by faults (Fig. 7): Coastal

(a)
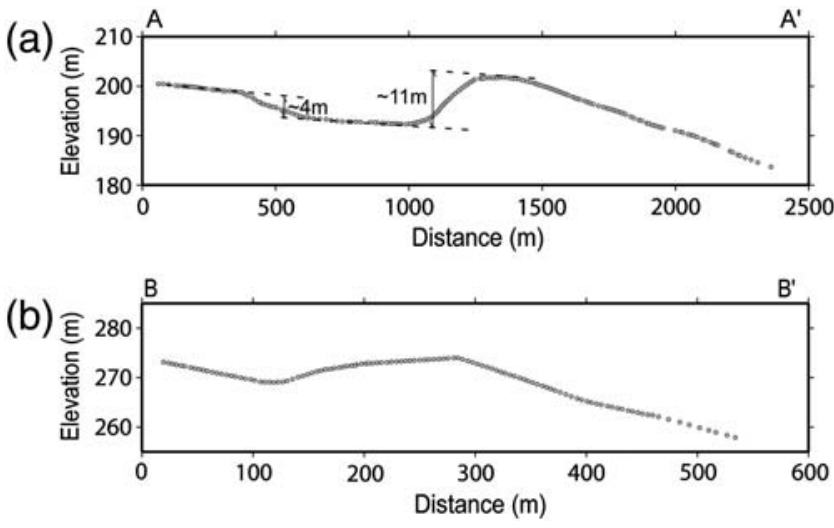

Figure 6. Topographic profiles across the Luyeh strand on the Lungtien and Yongan surfaces. Instrument uncertainties are at about the centimeter level and are too small to show at the plotted scale. (a) Topographic profile across the Luyeh fault on the Lungtien surface. Elevations were surveyed using a total station along a major road on the Lungtien surface. (b) Topographic profile across the Luyeh fault on the Yongan alluvial fan.

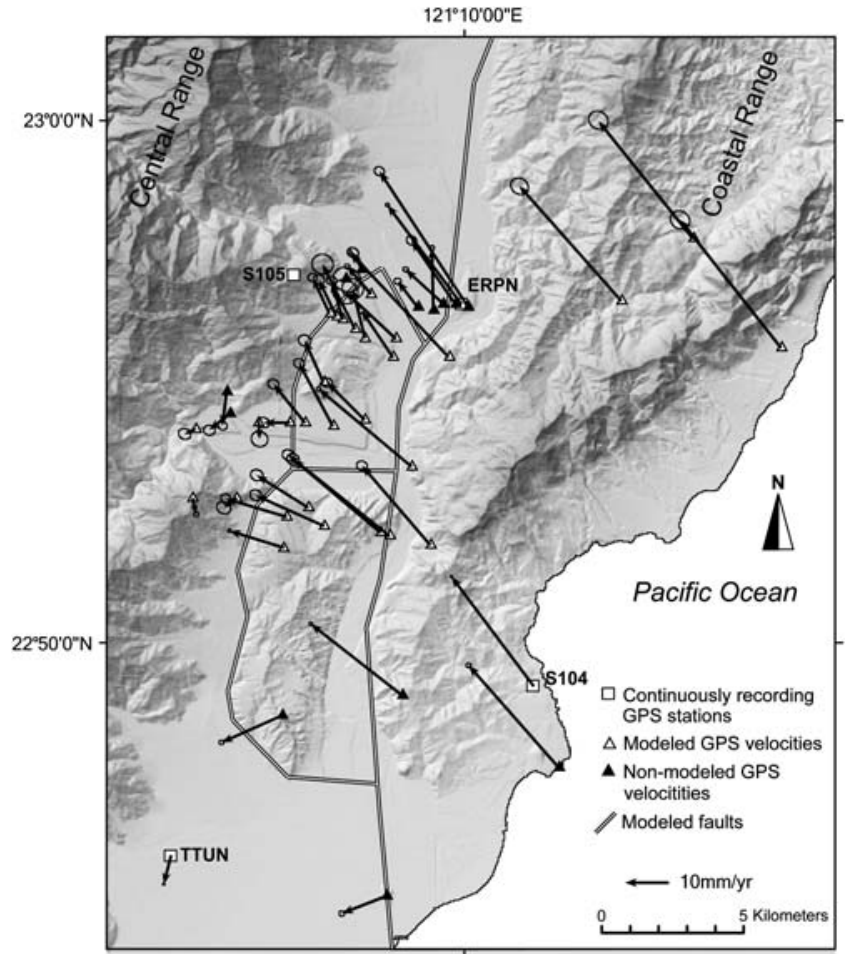

Figure 7. GPS velocity field with model faults. The open triangles are GPS velocities used as constraints. The filled triangles are velocities that were not used to constrain the model. The model relied primarily on GPS velocities around Yongan, Kaotai, Lungtien, and northern Peinanshan.

Range, Peinanshan and Kaotai, and Central Range (Fig. 3). The Peinan fault strand is the boundary between the easternmost block and the central block, and the Luyeh fault strand is the boundary between the central block and the western block. Because the central block shows a radial velocity pattern (Fig. 7), as well as different fault-bend geometry (Shyu et al., 2008; Fig. 8), an inferred fault along the Luyeh River divides the central block into the Kaotai block to the north and the Peinanshan block to the south by the Luyeh River (Fig. 3). This model fault separates the Luyeh and Peinan strands into northern and southern sections. Thus, the surface velocities of the Kaotai block are uniformly directed to the northwest, and those of the Peinanshan block to the westnorthwest in the north and to the west-southwest in the south.

The Luyeh and Peinan strands also link along the Luliao River in order to satisfy the block model requirements of polygon closure. The eastern boundary of the Coastal Range block is constrained by the offshore structure proposed by Shyu, Sieh, Chen, et al. (2005) (Fig. 2) and Malavieille et al. (2002) or the active thrust fault between Taiwan and Lutao that generated the $2004 M 6$ earthquake that occurred just west of Lutao. The Coastal Range block boundaries extend $1000 \mathrm{~km}$ away from the study area to avoid model boundary effects. In addition, the Central Range block is an exterior block, and the Central Range fault, which is obscured from Chihshang to the south, is ignored. In the Luyeh area, it may 
(a)
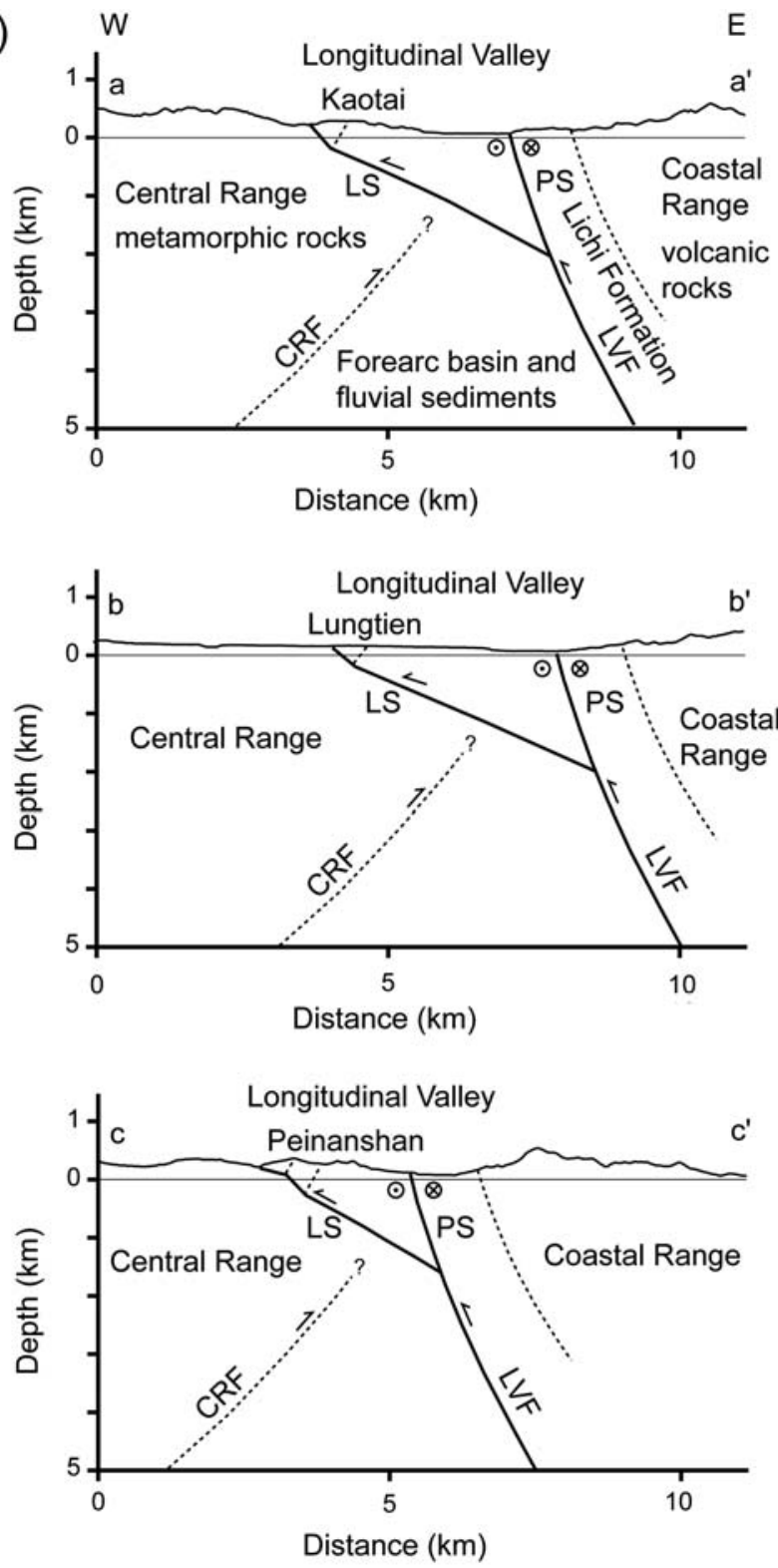

(b)
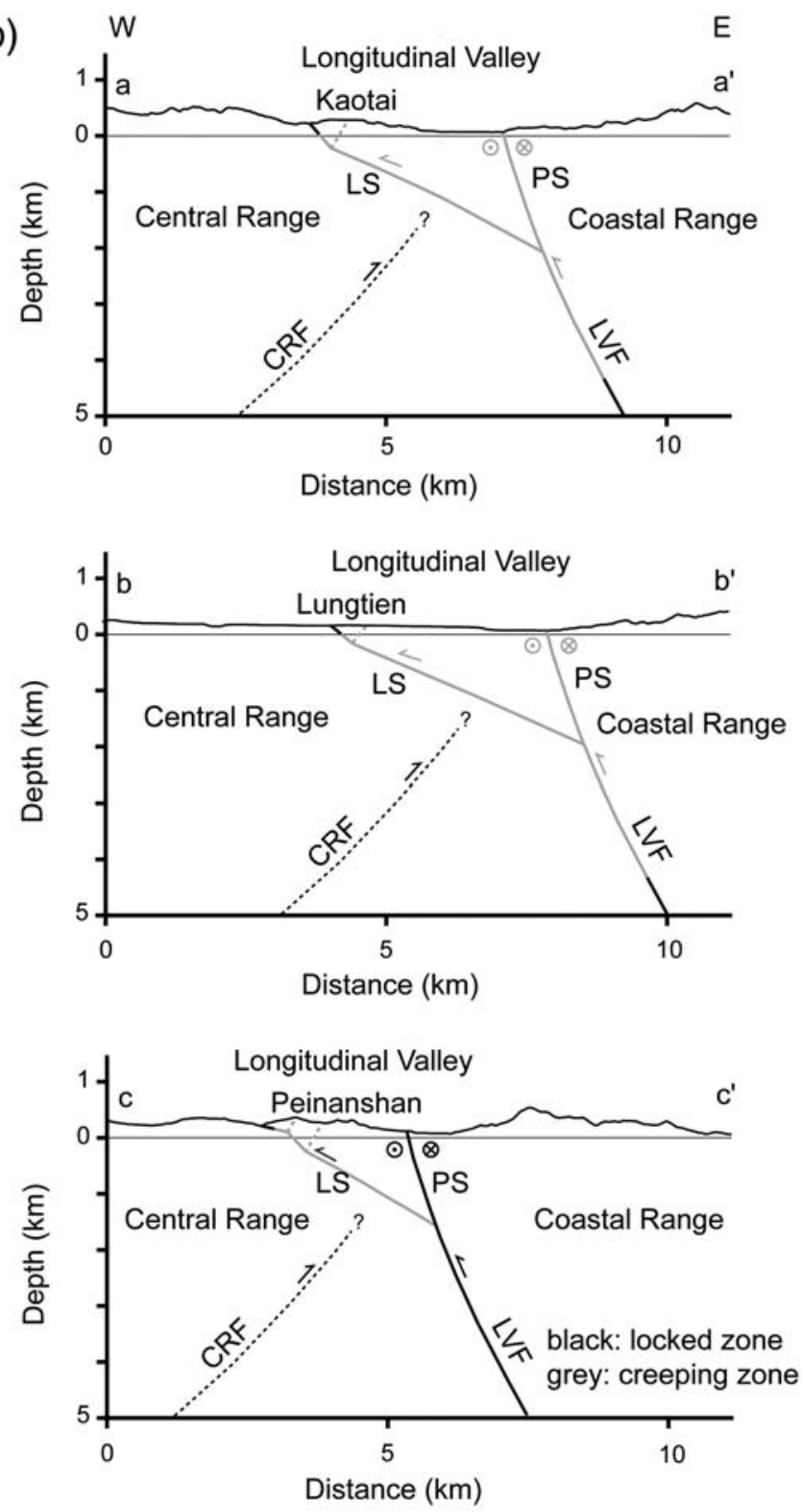

Figure 8. (a) Schematic cross sections of the Kaotai, Lungtien, and Peinanshan areas, modified from Shyu et al. (2008). The east-dipping Longitudinal Valley fault branches into the Peinan and Luyeh strands. The west-dipping Central Range fault is blind in the Luyeh area and overridden by the Luyeh strand. The Central Range fault (CRF), Luyeh strand (LS), Longitudinal Valley fault (LVF), Peinanshan Conglomerate (PNS), and Peinan strand (PS) are indicated in (a) and (b). (b) Cross sections depicting creeping (gray) and locked (black) sections of the Luyeh and Peinan strands at the latitude of Kaotai, Lungtien, and Peinanshan.

lie at depth under the cross-cutting Luyeh strand (Shyu et al., 2006; Shyu et al., 2008).

\section{Fault Location and Geometry}

A priori fault location, orientation, and locking depth constrain the crustal fault block model. Previous studies and field surveys provide insights on fault location and geometry that are simplified for our block model. The detailed parameters of the model faults are summarized in Table 2. The location of major structures in the Luyeh area is constrained by recent mapping by Shyu et al. (2002) and Shyu et al. (2008). Based on Shyu et al. (2008), the Longitudinal Valley fault intersects the surface along the western edges of Pingting terraces as multiple strands south of Rueiyuan. To the south, the Peinan strand displaces surfaces along the western edge of the Coastal Range to the northeast tip of the Peinanshan around Sanli (Fig. 3). The southern extent of the Peinan strand remains obscure and may lie along the Peinan River.

The Luyeh fault is located along the western edge of the Peinanshan, extends to the north through the Lungtien surface and the Mabei valley, which lies between Kaotai and the Central Range, and turns into a series of parallel synclines and anticlines north of Kaotai (Fig. 3). In the model, the 
Table 2

Summary Parameters of Model Faults

\begin{tabular}{lccc}
\hline \multicolumn{1}{c}{ Fault Segment } & Dip $\left({ }^{\circ} \mathrm{E}\right)$ & $\begin{array}{c}\text { Locking } \\
\text { Depth }(\mathrm{km})\end{array}$ & $\begin{array}{c}\text { Buried } \\
\text { Depth }(\mathrm{km})\end{array}$ \\
\hline Longitudinal Valley fault & 55 & 15.0 & 5 \\
Northern Peinan strand & 55 & 15.0 & 5 \\
Southern Peinan strand & 55 & 15.0 & 0 \\
Northern Luyeh strand & 30 & 0.1 & 0 \\
Southern Luyeh strand & 30 & 0.1 & 0 \\
\hline
\end{tabular}

Longitudinal Valley fault around Pingting and the northern Luyeh strand are treated as a single fault strand. The modeled Longitudinal Valley fault lies along a major scarp on the Pingting terraces and then is separated into two fault strands. To the south, the faults join together around the southern corner of the Peinanshan, where the Luyeh strand turns to the east-west direction and decreases activity (Shyu et al., 2008).

Because there are few seismic profiles of the Longitudinal Valley, focal mechanisms and the distribution of microseismicity constrain the subsurface geometry of the Longitudinal Valley fault. Focal mechanism solutions indicate a thrust fault geometry for the Longitudinal Valley fault with a strike of $25^{\circ}$ and a dip of $54^{\circ}$ to the east (Kuochen et al., 2004). In light of the relocation of microseismicity in the Longitudinal Valley (Lee et al., 2003; Kuochen et al., 2004) and the relocation of the main shock and aftershocks of the Chengkung earthquake (Wu et al., 2006), the Longitudinal Valley fault plane dips about $55^{\circ}$ and becomes shallower at greater depth. To the south, however, the Longitudinal Valley fault shows few changes in dip, even along the Peinan strand. Therefore, the model assigns a $55^{\circ} \mathrm{E}$ dip to the Longitudinal Valley fault and the Peinan strand.

The Luyeh strand is modeled as an east-dipping thrust fault (Lee et al., 1998; Shyu et al., 2002). With no seismic profile or background seismicity in the Peinanshan area, the fault geometry of the Luyeh strand is inferred from topographic expression and geologic data. Based on geomorphologic and structural analysis by Shyu et al. (2008), the Luyeh strand shows fault-bend geometry that generates a faultpropagation fold north of the Luyeh River and a fault-bend and fault-propagation fold to the south (Fig. 8a). Because the block model requires a fixed fault dip, the Luyeh strand is modeled as a shallowly dipping fault.

The model also assigns an a priori slip rate on the Longitudinal Valley fault north of the Luyeh area. GPS results from the Longitudinal Valley (Yu and Kuo, 2001) yields an average shortening rate of $28.5 \mathrm{~mm} / \mathrm{yr}$ across the Longitudinal Valley fault from coastal (far-field) stations to sites in the foot wall. Thus, a $50 \mathrm{~mm} / \mathrm{yr}$ slip rate of the Longitudinal Valley fault is the imposed fit with the fault dip at $55^{\circ}$.

\section{Locking Depth}

The model assigned a 15-km locking depth for the Longitudinal Valley fault, and the Peinan strand follows
Shyu, Sieh, Chen, et al. (2005), although some deeper earthquakes occur in eastern Taiwan. Far-field GPS velocities (S221, S214, and S232) show high rates that gradually decrease closer to the fault, also suggesting the locked patch. We adopted the $15-\mathrm{km}$ locking depth in the model, after testing results against other values.

One additional complication is that the Longitudinal Valley fault is creeping along strike. According to the GPS data that show discrepancies of near-fault velocities across every fault branch (Fig. 4a), the Longitudinal Valley fault creeps across Pingting terraces around Rueiyuan (Fig. 3). The GPS velocity discrepancies across the Peinan River also suggest near-surface creeping. There, the creeping portion is shallow and may reach the surface. Using the coseismic deformation modeling of the 2003 Chengkung earthquake (Chen et al., 2005; Wu et al., 2006) that implies no fault slip at shallower depth $(<5 \mathrm{~km})$, the Longitudinal Valley and the northern Peinan strand are creeping near the surface and, thus, are assigned a buried depth of $5 \mathrm{~km}$. To the south, however, no significant velocity discrepancy exists between stations S212 and S217 and the gradual change in direction from station S218 to S215 indicates the fault is locked at the surface around the northeastern corner of Peinanshan (Fig. 3).

For the Luyeh strand, the leveling data (Fig. 5) on the Lungtien surface show growth of the monocline by creep. However, no cracks breach man-made structures on the surface. Thus, the creeping patch may not reach the surface, although it is most likely very shallow. The GPS velocities across the Luyeh strand (Fig. 4c) also support the hypothesis that the Luyeh fault is creeping, and the GPS velocities on the Lungtien surface and northern Peinanshan show an obvious velocity decline across the Luyeh strand. The GPS velocities that lie very close to and on the both side of the Luyeh strand are similar (S197 and S207), suggesting that the Luyeh strand is not creeping at the surface at rates discernible by GPS (Fig. 5). Interferometric synthetic aperture radar measurements also support no surface creep right across the Luyeh strand (Hsu and Bürgmann, 2006). These data indicate that the Luyeh strand is creeping, but creep may not reach the surface, indicating a very shallow locking depth of the Luyeh strand for the block model. This locking depth does not represent the plastic-ductile transition, and it more likely represents the tip of creeping zone. Inversion of our block model over buried depths of the Luyeh strand smaller than $0.5 \mathrm{~km}$ results in little variance in modeled slip rates and near-fault velocity residuals.

\section{Modeling}

The block model presented here follows the methodology of Meade et al. (2002) and Meade and Hager (2005). This model calculates the effects of elastic-strain accumulation and block motions with a fault dislocation in an elastic half-space following Okada (1985), using a Poisson's ratio of 0.25 . To avoid numerical problems associated with 
calculating displacements from dislocations with infinite depth extent (Meade et al., 2002), the study area on the curved surface is projected onto a plane. While this effect is very small over distances in the Luyeh area, we used the Meade et al. (2002) formalism nonetheless. The model assumes no internal block deformation, so that kinematic consistency can be enforced, and a single locking depth for each fault. We also assume negligible temporal variation during the interseismic interval and neglect the viscoelastic relaxation effect. This assumption is only robust if the relaxation time is greater than half the repeat time between earthquakes (Meade et al., 2002). Using this approach, fault slip rates can be directly estimated by kinematically consistent inversion from the GPS data. The inversion method requires block fault parameters and a minimum of two GPS stations located in each block. The method calculates fault slip rates and block motions by a weighted least squares inversion (McClusky et al., 2001).

In our model, we only use horizontal GPS data and exclude the vertical GPS and leveling data, because the vertical GPS velocities are less accurate and the leveling data are conducted independently without surveying adjustment. Considering that most GPS stations around Pingting terraces are located between many branches of the Longitudinal Valley fault (Fig, 4b), and the foot-wall sites may sit in a different block from the Central Range block in our model because they might be between the Longitudinal Valley fault and the buried Central Range fault (Fig. 2), we infer fault characteristics from those sites around Pingting instead of inverting them in the model. While the velocity field in southernmost Peinanshan is not consistent with the rest of the block, a more complex geometry is not supported by the density of observations and would not meet the requirement of two data points in each block. Such isolated velocities were omitted in the model. Therefore, the GPS velocities around Yongan, Lungtien, and northern Peinanshan constrain the inversion (Fig. 3).

\section{Results}

The inversion provides strike-slip, dip-slip, and tensileslip or deformation rates for each model fault, with observed, modeled, and residual velocity fields. The slip rates on each fault segment of the Luyeh and Peinan strands are summarized in Table 3 and Figure 8a.

The model results provide estimates of fault slip and strain partitioning between the two fault strands, the Peinan and Luyeh strands. Because the Luyeh strand is the only model boundary fault between the Central Range block and the Kaotai-Peinanshan blocks (the Central Range fault is neglected), the modeled slip rates on the Luyeh strand incorporates any composite fault motions. On the hanging-wall block of the Luyeh strand, some residual velocities are perhaps larger due to fault dip changes on the Luyeh strand or internal deformation of the Kaotai or Peinanshan blocks. Two areas show residuals of over $5 \mathrm{~mm}$. The first, stations S212 and S217 show little velocity difference, indicating a
Table 3

Model Slip for Major Faults in the Luyeh Area

\begin{tabular}{crcr}
\hline Fault Segment & \multicolumn{1}{c}{$\begin{array}{c}\text { Strike-Slip* } \\
\text { (mm/yr) }\end{array}$} & Dip-Slip $^{\dagger}(\mathrm{mm} / \mathrm{yr})$ & Tensile $^{\ddagger}(\mathrm{mm} / \mathrm{yr})$ \\
\hline LVF1 & $26.2 \pm 0.3$ & $40.5 \pm 0.3$ & \\
LVF2 & $10.6 \pm 0.3$ & $58.3 \pm 0.3$ & \\
PS1 & $3.1 \pm 0.1$ & $47.3 \pm 0.2$ & \\
PS2 & $12.3 \pm 0.1$ & $39.8 \pm 0.3$ & \\
PS3 & $17.2 \pm 0.1$ & $29.3 \pm 0.3$ & \\
PS4 & $16.5 \pm 0.5$ & $8.9 \pm 0.4$ & \\
PS5 & $15.4 \pm 0.4$ & $20.8 \pm 1.0$ & \\
PS6 & $18.9 \pm 0.5$ & $22.2 \pm 1.7$ & \\
LS1 & $11.6 \pm 0.2$ & $4.3 \pm 0.2$ & \\
LS2 & $14.1 \pm 0.2$ & $5.7 \pm 0.2$ & \\
LS3 & $15.2 \pm 0.2$ & $8.3 \pm 0.2$ & \\
LS4 & $-9.5 \pm 0.2$ & $21.1 \pm 0.2$ & \\
LS5 & $-1.1 \pm 0.2$ & $19.9 \pm 0.2$ & \\
LS6 & $6.0 \pm 0.2$ & $14.4 \pm 0.4$ & \\
LS7 & $0.7 \pm 0.3$ & $11.8 \pm 0.7$ & \\
LS8 & $3.7 \pm 0.1$ & $7.0 \pm 1.0$ & \\
LS9 & $5.9 \pm 0.7$ & $0.0 \pm 0.9$ & \\
TF1 & $-8.8 \pm 0.2$ & & \\
TF2 & $-15.5 \pm 0.2$ & & \\
\end{tabular}

*A minus sign indicates a right-lateral fault; otherwise the fault is left-lateral.

${ }^{\dagger}$ All faults are reverse faults.

${ }^{\ddagger}$ A minus sign indicates opening of the fault; otherwise, closure.

locked fault at depth (Fig. 4c). The second place is the foot wall of the Luyeh strand on the Lungtien surface. The velocities S203, S204, S205, and S206 show very different patterns from those in the same block, such as S211. This may reflect differences between locking depths of strike-slip and dip-slip components or by minor structures in the foot wall, such as a possible branch of the Central Range fault on the Lungtien surface (Fig. 6). The residual of S219 is also large. It may be affected by minor structures at northern Peinanshan (Fig. 3).

We also modeled the Kaotai and Peinanshan as one block, inverting GPS velocities around southernmost Peinanshan: both results show systematic misfit. In a three-block model, residuals around Kaotai show northward patterns together, and those around northern Peinanshan show southward patterns. This kinematic inconsistency suggests that the Kaotai and northern Peinanshan blocks are different blocks, or that the block is not internally rigid: our data set does not allow us to discriminate a more complex block geometry while meeting the required minimum number of observations for each block. If our inversion includes velocities around southern Peinanshan and Taitung Plain, residuals for those stations around southern Peinanshan and Taitung Plain will become considerably large and show systematically southwestward movements, suggesting that the southern part of Peinanshan might be a separated block from northern Peinanshan. The southern block may be separated from minor structures in Peinanshan, coinciding with normal faulting within southern Peinanshan observed in the field. 


\section{Discussion}

A GPS-constrained block model provides estimates of short-term fault slip rates for both the Luyeh and Peinan strands of the Longitudinal Valley fault at the latitude of the Luyeh area, providing direct constraints on strain accumulation across active faults known to be both seismogenic and creeping. The results show different fault slip rates on each fault segment yielding estimates of strain partition and seismic potential of the southernmost Longitudinal Valley.

The Longitudinal Valley fault is one of the dominant structures between the Eurasia and Philippine Sea plates. About $30 \mathrm{~mm} / \mathrm{yr}$ of present-day shortening ( $\mathrm{Yu}$ and Kuo, 2001), or 30\% of the total plate convergent rate (Angelier et al., 2000), is accommodated across the Longitudinal Valley fault. This plate boundary shows significant fault slip with surface creep and frequent seismic events. Fault characteristics, slip rates, and creeping features vary conspicuously along the strike of the Longitudinal Valley fault. In the Luyeh area, the southernmost part of the Longitudinal Valley fault, the fault is partitioned into two strands, and the crustal deformation here is primarily accommodated on these two strands (Lee et al., 1998; Yu and Kuo, 2001). Based on our block model, the slip rates differ between the two strands and vary in the northern and southern section, revealing more detail than previous studies (e.g., Lee et al., 1998; Yu and Kuo, 2001).

\section{Fault Characteristics and Strain Partitioning}

GPS-constrained model results show that the Peinan strand is thrust dominant at the north end, and with decreasing dip-slip rates and increasing sinistral rates to the south. At the northern section of the Peinan strand, the slip rates vary from about $40 \mathrm{~mm} / \mathrm{yr}$ dip-slip to about $16 \mathrm{~mm} / \mathrm{yr}$ leftlateral strike-slip and $9 \mathrm{~mm} / \mathrm{yr}$ dip-slip. To the south across the Luyeh River, the Peinan strand shows a consistent $15-18 \mathrm{~mm} / \mathrm{yr}$ sinistral rate, but the dip-slip rates vary from 8 to $20 \mathrm{~mm} / \mathrm{yr}$. The Luyeh strand slips at similar rates on each segment north of the Luyeh River. South of the Luyeh River, the Luyeh strand has a dip-slip rate of $15 \mathrm{~mm} / \mathrm{yr}$ and progressively decreasing slip rates to the south. The decreasing pattern of slip rates on the southern Luyeh strand coincides with geomorphic patterns observed in the field. Because the model considers coherent block motions, slip rates on bounding faults may vary due to orientation changes. For example, three northern segments of the southern Luyeh strand show a strong right-lateral motion or weak left-lateral motion (Fig. 9).

Several previous studies estimate horizontal shortening or displacement rates across the two faults. Using a discontinuous model and trilateration data, Lee et al. (1998) propose a model of transpressive faulting for the southern Peinanshan area and estimate relative motion of $22 \mathrm{~mm} / \mathrm{yr}$ in the direction of $353^{\circ}$ and $12 \mathrm{~mm} / \mathrm{yr}$ in the direction of $280^{\circ}$ across the Luyeh fault. Hu et al. (2001) calculate a total displacement of $33 \mathrm{~mm} / \mathrm{yr}$ in the direction of $318^{\circ}$ using a

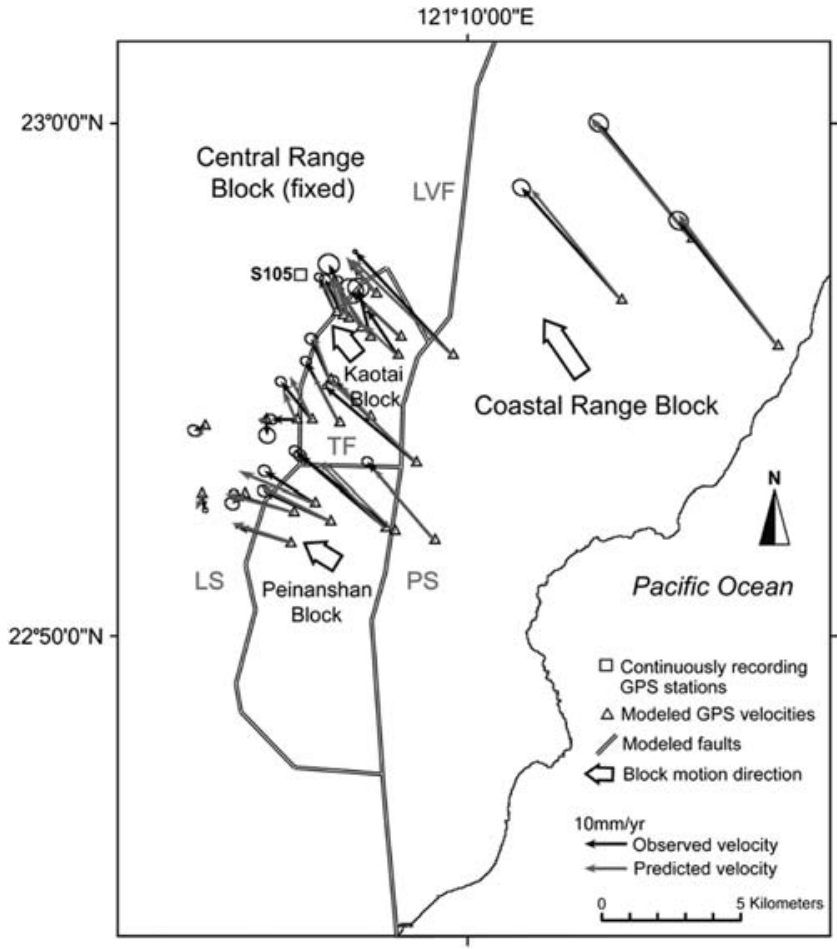

Figure 9. Modeled slip rates for major faults in the Luyeh area. The black arrows are observed velocities and the gray arrows are model-predicted velocities. The large white arrows show model block motion. Estimated slip rates and one-sigma uncertainty are shown for major fault segments. For each pair, the upper rate is the strike-slip component, and the lower rate is the dip-slip component. The detailed slip rates are presented in Table 3. The Luyeh strand (LS), Longitudinal Valley fault (LVF), Peinan strand (PS), and an inferred tear fault (TF) are indicated.

three-dimensional distinct-element model. To the north, previous GPS observations in the Longitudinal Valley (Yu and Kuo, 2001) show a relative velocity of $21.8 \mathrm{~mm} / \mathrm{yr}$ along an azimuth of $316^{\circ}$ across the eastern Coastal Range fault and $13-15 \mathrm{~mm} / \mathrm{yr}$ along azimuths of $295^{\circ}-326^{\circ}$ across the Luyeh fault around the Luyeh area. Because the previous studies only estimate relative motion across these two faults, our model provides the first estimate of partitioned slip rates on both faults. These estimates provide general constraints on horizontal shortening across local faults. Our results show that the Peinan and Luyeh strands have oblique motion and slip rates vary along strike. According to the slip rates between the two strands, the strain partitioning at this latitude is not as simple as a transpressive model proposed by Lee et al. (1998). Instead, our model results are more consistent with recent mapping results and field investigation (Shyu et al., 2008) and surface deformation from persistent scatterer interferometric synthetic aperture radar (PS-InSAR; Peyret et al., 2011).

Based on our results, the Luyeh strand shows progressively decreasing fault slip rates bilaterally from the middle, which is corroborated by geomorphic features and field investigation (Shyu et al., 2008). Here, the fault characteristics 
observed from geodetic data are similar to those from geomorphic features and field investigations, implying that longterm fault behaviors are also manifest in short-term geodetic observations. On the Lungtien surface, the Luyeh strand has a dip-slip rate of $8.3 \mathrm{~mm} / \mathrm{yr}$, generating a smaller uplift rate than that suggested by leveling (Fig. 5) but more consistent with the uplifted rates derived from PS-InSAR (Peyret et al., 2011). However, topographic profiles (Fig. 6a) and geologic mapping (Shyu et al., 2008; Fig. 7) suggest the Luyeh strand has a fault bend and increases the dip angle close to the surface. The observed rate of uplift from leveling taken with the model block motions implies a dip angle of $45^{\circ}$ rather than $30^{\circ}$. At the latitude of northern Peinanshan, the Luyeh strand is thrust dominant, and dip slip along the Peinan strand significantly decreases. Dip-slip motion missing from the Peinan strand is partitioned onto the Luyeh strand. Here, northwestern Peinanshan collides with the Central Range and the faultrelated folds are generated within the hanging-wall block. The fault dip close to the surface of the Luyeh strand around northern Peinanshan is gentler than the fault dip around the Lungtien area (Fig. 8a). This lesser fault dip may cause an increase in dip-slip motion on the Luyeh strand. To the south, slip decreases along the Luyeh strand and major shortening rates are concentrated along the Peinan strand.

The model results and leveling data can also be compared to geologic uplift rates. At the area of the Pingting terraces, the modeled dip-slip rate of $40.5 \mathrm{~mm} / \mathrm{yr}$ (Fig. 9) implies $33 \mathrm{~mm} / \mathrm{yr}$ vertical offset. For a fault dip of $70^{\circ}$ near the surface, the vertical offset rate could be as high as $38 \mathrm{~mm} / \mathrm{yr}$. The geologic rate across two major fault scarps at the Pingting terraces is about $28 \mathrm{~mm} / \mathrm{yr}$ (Shyu et al., 2008). The discrepancy between modeled and geologic relative uplift rates suggest that about $5-10 \mathrm{~mm} / \mathrm{yr}$ vertical separation is absorbed by other minor fault branches around Pingting, or that present-day slip rates are higher than longterm geologic rates. On the Lungtien surface, the minimum average vertical slip rate of the strand has been about $4.5 \mathrm{~mm} / \mathrm{yr}$ over the past $3000 \mathrm{yr}$, based on a $15 \mathrm{~m}$ fault-scarp height determined from the digital elevation model (DEM; Shyu et al., 2008). A local total station survey yields a refined estimate of an $11 \mathrm{~m}$ fault-scarp height along the Luyeh strand cutting the Lungtien surface, thus the long-term vertical slip rate may be even less. Both rates are smaller than the current $6 \mathrm{~mm} / \mathrm{yr}$ based on leveling, suggesting a higher present-day creep rate.

\section{Surface Creep along the Southernmost Longitudinal Valley}

From geodetic observations and geologic evidence, the Longitudinal Valley fault shows significant aseismic shallow creep at Chihshang (Angelier et al., 1997; Lee et al., 2001; Lee et al., 2003), Fuli (Yu and Liu, 1989), and Yuli (Yu and Kuo, 2001) with the presence of a deep seismogenic zone and moderate to large earthquakes (e.g., Chen et al., 2005; Shyu et al., 2007). The creep rates are about $15-20 \mathrm{~mm} / \mathrm{yr}$
(Lee et al., 2001; Lee et al., 2003) in Chihshang, $30 \mathrm{~mm} / \mathrm{yr}$ in the north (Yu and Liu, 1989) in Fuli, and $24 \mathrm{~mm} / \mathrm{yr}$ (Yu and Kuo, 2001) in Yuli. These observations may underestimate creep, because they are only derived from surface cracks across aqueducts or other man-made structures or from short-distance leveling with scattered measurements. The creeping section of the Longitudinal Valley fault is a nearsurface phenomenon with fault locking below the creeping zone. Consequently, earthquakes along the Longitudinal Valley occur due to fault dislocation within locked patches.

Based on the GPS velocity field and modeling results, the Longitudinal Valley fault records near-surface creeping around the Luyeh area. The Luyeh strand displays shallow creep and the creep tip is extremely close to the surface, based on leveling data. The Longitudinal Valley fault around Rueiyuan and the northern Peinan strand are creeping at shallow depths. The southern Peinan strand is locked around northern Peinanshan. The bottom of the Luyeh strand may branch from the lower creeping section of the Peinan strand. This may result in similar creeping features for both strands. South of the Luyeh River, the Luyeh strand records creep, but the Peinan strand is somewhat locked due to structure migration or transition between different fault characteristics (Fig. 8b).

Further south, Yu et al. (1992) measured approximately $25 \mathrm{~mm} / \mathrm{yr}$ horizontal and only $2 \mathrm{~mm} / \mathrm{yr}$ vertical creep rates across the Taitung bridge (Fig. 3) southeast of Peinanshan. Although the dip-slip motion across the Peinan strand here is smaller than in any northern segment, the $2 \mathrm{~mm} / \mathrm{yr}$ rate is still small compared to the creep rates around Chihshang and Rueiyuan. In addition, evidence for surface creep is not present in the field, and sparse GPS velocities decrease toward the fault. Together these suggest a shallow locking depth rather than surface creep around the southernmost Peinan strand. However, these recent observations do not provide enough information to estimate the locking depth and fault creep precisely at this place.

The southernmost Peinan strand shows a different pattern. In addition, the Luyeh strand also changes orientation and joins the Peinan strand just southwest of the Taitung bridge and close to the transition zone between Taitung and the Lutao-Lanyu structural domains (Shyu, Sieh, Chen, et al., 2005). Because recent observations and models cannot resolve our block model near the area around southern Peinanshan and Taitung Plain, a denser GPS network is also needed there in order to observe fault characteristics and strain accumulation.

Creep along the southern Longitudinal Valley fault limit estimates of the potential magnitude of earthquakes. The Longitudinal Valley fault displays creep around Rueiyuan, which resembles the characteristics of the shallow creep of the Chihshang fault (e.g., Angelier et al., 1997) about $10 \mathrm{~km}$ north of the Luyeh area. The fault may act similarly from Chihshang to the northern Peinan strand near the southern end of the Chihshang segment of the Longitudinal Valley fault. 


\section{Estimates of Seismic Potential}

Seismic energy released during earthquakes is related to the area of fault rupture and the magnitude of fault slip. Based on regression equations by Wells and Coppersmith (1994), moment magnitude has relationship to rupture area $A\left(\right.$ in $\mathrm{km}^{2}$ ) such that

$$
M_{\mathrm{w}}=3.98+1.02 \times \log A, \text { for strike-slip faults, }
$$

and

$$
M_{\mathrm{w}}=4.33+0.90 \times \log A, \text { for reverse faults. }
$$

This analysis assumes a coseismic rupture patches along the length of the Luyeh and Peinan strands (Fig. 9). Because the Luyeh and Peinan strands have strike-slip as well as dipslip motion, we use both equations (1) and (2) to estimate moment magnitude (Table 4). Because the northern Peinan strand is creeping near the surface, we estimate two cases: (1) only rupture of its locked zone (5-15 km), and (2) whole patch rupture. The results show that the Luyeh strand could generate a $M_{\mathrm{w}} 6$ earthquake and the Peinan strand could generate a $M_{\mathrm{w}} 6.5$ earthquake. These two strands intersect at shallow depth and thus could fail concurrently, resulting in an earthquake as large as $M_{\mathrm{w}}$ 6.6. Although the Luyeh strand may have a maximum potential of $M_{\mathrm{w}} 6$, near-surface creeping and the very shallow locking depth suggest that this may be overestimated, and a likely maximum event for both strands is $M_{\mathrm{w}} 6.5$.

The estimate of moment magnitude depends on seismic moment $M_{0}$ (in dyn $/ \mathrm{cm}^{2}$ ), estimated by

$$
M_{0}=\mu D A \text {, }
$$

where $\mu$ is the shear modulus, commonly about $3 \times 10^{11} \mathrm{dyn} / \mathrm{cm}^{2}$ in the crust, and $D$ is the displacement on the area. Further, seismic moment is related to earthquake moment magnitude $M_{\mathrm{w}}$ such that

\section{Table 4}

Estimated Moment Magnitude of the Luyeh and Peinan Strands Related to Rupture Area

\begin{tabular}{lc}
\hline \multicolumn{1}{c}{ Fault } & $M_{\mathrm{w}}$ \\
\hline Strike-slip fault & \\
Luyeh strand & 6.0 \\
Peinan strand including creeping zone & 6.5 \\
Peinan strand excluding creeping zone & 6.4 \\
Two strands & 6.6 \\
Two strands excluding creeping zone of Peinan strand & 6.6 \\
Reverse fault & 6.1 \\
Luyeh strand & 6.5 \\
Peinan strand including the creeping zone & 6.5 \\
Peinan strand excluding the creeping zone & 6.7 \\
Two strands & 6.6 \\
Two strands excluding the creeping zone of Peinan strand &
\end{tabular}

$$
M_{\mathrm{w}}=2 / 3 \log M_{0}-10.73 .
$$

Because the block model provides slip rate estimates on each segment of the two strands, the moment accumulation can be calculated for likely recurrence intervals if the creep model is robust. The only recurrence interval estimates are at the Rueisuei segment of the Longitudinal Valley fault (Chen et al., 2006), however, which is more than $50 \mathrm{~km}$ away. Therefore, we just estimate a fault displacement for the Peinan and Luyeh strands and calculate the seismic moment based on the displacement. The investigation of the 1951 Chihshang surface rupture (Shyu et al., 2007) with a similar fault geometry reveals vertical displacements of $0.2-1.5 \mathrm{~m}$, and mostly less than $1 \mathrm{~m}$, an estimate we adopt as reasonable for the Peinan and Luyeh strands, with a rupture length of $15 \mathrm{~km}$ based on Wells and Coppersmith (1994). We calculate the seismic moment for each fault segment and evaluate the aggregate moment magnitude (Table 5). The estimated moment magnitude is 6.3 for the Luyeh strand and 6.6 for the Peinan strand if the creeping zone of the Peinan strand is excluded.

There are some remaining issues in the estimate using seismic moment. Based on the slip rate determinations presented here, a 1-m fault displacement indicates recurrence intervals of several decades for the two strands, but there is little to indicate such a record in the Luyeh area. Earthquakes may either be less frequent and larger than our estimates, or the effects of near-surface creep have obscured the record or affected the seismic moment budget.

It is reasonable, therefore, that $M_{\mathrm{w}} 6.5$ events are the largest common earthquakes that occur along the Peinan strand and, perhaps, are accompanied by large landslides on the poorly cemented Lichi Formation east of the Peinan River (Fig. 8a), similar to those along the east bank of the Peinan River (Shyu et al., 2008).

\section{Conclusions}

The southern Longitudinal Valley fault provides a natural laboratory for understanding the kinematics of an

Table 5

Estimated Moment Magnitude of the Luyeh and Peinan Strands Related to Annual Seismic Moment

\begin{tabular}{lccc}
\hline \multicolumn{1}{c}{ Fault } & $\begin{array}{c}\text { Annual Moment } \\
\text { Accumulation } \\
(\mathrm{dyn} \cdot \mathrm{cm})\end{array}$ & $\begin{array}{c}\text { Fault } \\
\text { Displacement } \\
(\mathrm{cm})\end{array}$ & $M_{\mathrm{w}}$ \\
\hline $\begin{array}{l}\text { Luyeh strand } \\
\text { Peinan strand including the } \\
\quad \text { creeping zone }\end{array}$ & $\begin{array}{c}3.22 \times 10^{25} \\
8.67 \times 10^{25}\end{array}$ & 100 & 6.3 \\
$\begin{array}{l}\text { Peinan strand excluding the } \\
\text { creeping zone }\end{array}$ & $7.83 \times 10^{25}$ & 100 & 6.6 \\
Two strands & $1.19 \times 10^{26}$ & 100 & 6.6 \\
$\quad \begin{array}{l}\text { Two strands excluding the } \\
\text { creeping zone of the }\end{array}$ & $1.11 \times 10^{26}$ & 100 & 6.7 \\
$\quad$ Peinan strand & & &
\end{tabular}


onshore plate boundary that simultaneously demonstrates both fault creep and seismogenic strain accumulation. A GPS-constrained kinematically consistent block model provides estimates of fault slip rates for both the Luyeh and Peinan strands of the Longitudinal Valley fault in the Luyeh area. Our model estimates strain partitioning and variations in oblique motions between the two strands. The Peinan strand is a thrust fault in the north, with decreasing dipslip and increasing sinistral slip to the south. South of the Luyeh River, the Peinan strand has lower slip rates in the dip direction. The Luyeh strand shows similar oblique motion north of the Luyeh River and becomes thrust-dominated in the northern Peinanshan area. Slip rates are highest at its center and progressively decrease toward the south and north ends. The Longitudinal Valley fault near Rueiyuan and the northern Peinan strand record surface creep and are locked at a deeper depth. The southern Peinan strand also appears locked, whereas the Luyeh strand records near-surface creep. Therefore, significant strain is released through fault creep on the southernmost Longitudinal Valley fault, limiting estimates of potential magnitude for local earthquakes.

Based on seismic moment and fault parameters, potential earthquake magnitude may exceed 6.5, the largest hazard posed by potential rupture within the locked zone of the Peinan strand. An earthquake here could also trigger landslides along the Peinan River. For a better understanding of local crustal deformation, additional GPS experiments are required around southernmost Peinanshan and Taitung Plain.

\section{Data and Resources}

Data sets from three geodetic techniques including GPS (three campaigns), leveling, and total station measurements are presented in this study. These data were collected by the authors R. Y. Chuang, H. Y. Chen, J. B. H. Shyu, and L. H. Chung using instruments from the Department of Geosciences of the National Taiwan University and IESAS, and these data are available by request from us. GPS data analysis was conducted by $\mathrm{H}$. Y. Chen and S. B. Yu. The three earthquake catalogs in Figure 2 came from published sources listed in the references. The DEM data used in the figures are from the Ministry of the Interior of the Republic of China and were plotted using Generic Mapping Tools (GMT) and ArcGIS software.

\section{Acknowledgments}

This research was supported by the National Science Council of Taiwan as project number NSC 98-2119-M-001-031. We thank the Department of Geosciences of the National Taiwan University and IESAS for providing instruments for field observations. We are also grateful for field assistance provided by IESAS in the installation of benchmarks and collection of data. The new data sets presented here formed the basis of the M.S. Thesis of R. Y. Chuang at Central Washington University.

\section{References}

Angelier, J., H.-T. Chu, and J.-C. Lee (1997). Shear concentration in a collision zone: Kinematics of the Chihshang fault as revealed by outcropscale quantification of active faulting, Longitudinal Valley, eastern Taiwan, Tectonophysics 274, 117-143, doi 10.1016/S0040-1951(96) 00301-0.

Angelier, J., H.-T. Chu, J.-C. Lee, and J.-C. Hu (2000). Active faulting and earthquakehazard: The case study of the Chihshang fault, Taiwan, J. Geodyn. 29, 151-185, doi 10.1016/S0264-3707(99)00045-9.

Chen, H.-Y., S.-B. Yu, L.-C. Kuo, and C.-C. Liu (2006). Coseismic and postseismic surface displacements of the 10 December $2003\left(M_{\mathrm{w}} 6.5\right)$ Chengkung, eastern Taiwan, earthquake, Earth Planets Space 58, $5-21$.

Cheng, S. N., Y. T. Yeh, and M. S. Yu (1996). The 1951 Taitung earthquake in Taiwan, J. Geol. Soc. China 39, 267-285.

Hsu, L., and R. Bürgmann (2006). Surface creep along the Longitudinal Valley fault, Taiwan from InSAR measurements, Geophys. Res. Lett. 33, no. 6, L06312, 4, doi 10.1029/2005GL024624.

Hsu, Y.-J., S.-B. Yu, and H.-Y. Chen (2009). Coseismic and postseismic deformation associated with the 2003 Chengkung, Taiwan, earthquake, Geophys. J. Int. 176, 420-430, doi 10.1111/j.1365-246X. 2008.04009.x.

Hu, J.-C., J. Angelier, C. Homberg, J.-C. Lee, and H.-T. Chu (2001). Threedimensional modeling of the behavior of the oblique convergent boundary of southeast Taiwan: Friction and strain partitioning, Tectonophysics 333, 261-276, doi 10.1016/S0040-1951(00)00278-X.

Hugentobler, U., S. Schaer, and P. Fridez (2001). Bernese GPS software, version 4.2, Astrology Institute, University of Berne, Berne, Switzerland.

Kuochen, H., Y.-M. Wu, C. H. Chang, J.-C. Hu, and W.-S. Chen (2004). Relocation of eastern Taiwan earthquakes and tectonic implications, Terr. Atmos. Ocean. Sci. 15, 647-666.

Kuochen, H., Y.-M. Wu, Y.-G. Chen, and R.-Y. Chen (2007). $2003 M_{\mathrm{w}} 6.8$ Chengkung earthquake and its related seismogenic structures, J. Asian Earth Sci. 31, 332-339, doi 10.1016/j.jseaes.2006.07.028.

Lee, J. C., J. Angelier, H. T. Chu, S. B. Yu, and J. C. Hu (1998). Plate boundary strain partitioning along the sinistral collision suture of the Philippine and Eurasian plates: Analysis of geodetic data and geological observations in southeastern Taiwan, Tectonics 17, 859-871, doi 10.1029/98TC02205.

Lee, J.-C., J. Angelier, H.-T. Chu, J.-C. Hu, and F.-S. Jeng (2001). Continuous monitoring of an active fault in a plate suture zone: A creepmeter study of the Chihshang fault, eastern Taiwan, Tectonophysics 333, 219-240, doi 10.1016/S0040-1951(00)00276-6.

Lee, J.-C., J. Angelier, H.-T Chu, J.-C. Hu, F.-S. Jeng, and R.-J. Rau (2003). Active fault creep variations at Chihshang, Taiwan, revealed by creep meter monitoring, 1998-2001, J. Geophys. Res. 108, no. 2528, 21, doi 10.1029/2003JB002394.

Lee, J.-C., H.-T. Chu, J. Angelier, J.-C. Hu, H.-Y. Chen, and S.-B. Yu (2006). Quantitative analysis of surface coseismic faulting and postseismic creep accompanying the 2003, $M_{\mathrm{w}}=6.5$, Chengkung earthquake in eastern Taiwan, J. Geophys. Res. 111, no. B02405, 21, doi 10.1029/2005JB003612.

Malavieille, J., S. E. Lallemand, S. Dominquez, A. Deschamps, C.-Y. Lu, C.-S. Liu, P. Schnürle, J. Angelier, J. Y. Collot, B. Deffontaines, M. Fournier, S.-K. Hsu, J. P. Le Formal, S.-Y. Liu, J. C. Sibuet, N. Thareau, F. Wang, and The ACT (Active Collision in Taiwan) Scientific Crew (2002). Arc-continent collision in Taiwan: New marine observations and tectonic evolution, in Geology and Geophysics of an Arc-Continent Collision, Taiwan, A. Basu and M. E. Bickford (Editors), Geol. Soc. Am. Spec. Pap. 358, 187-211, doi 10.1130/0-8137-23582.187 .

McClusky, S. C., S. C. Bjornstad, B. H. Hager, R. W. King, B. J. Meade, M. M. Miller, F. C. Monastero, and B. J. Souter (2001). Present day kinematics of the Eastern California Shear Zone from a geodetically constrained block model, Geophys. Res. Lett. 28, 3339-3372. 
Meade, B. J., and B. H. Hager (2005). Block models of crustal motion in southern California constrained by GPS measurements, J. Geophys. Res. 110, no. B03403, 19, doi 10.1029/2004JB003209.

Meade, B. J., B. H. Hager, S. C. McClusky, R. E. Reilinger, S. Ergintav, O. Lenk, A. Barka, and H. Özener (2002). Estimates of seismic potential in the Marmara Sea region from block models of secular deformation constrained by Global Positioning System measurements, Bull. Seismol. Soc. Am. 92, 208-215, doi 10.1785/0120000837.

Okada, Y. (1985). Surface deformation due to shear and tensile faults in a half-space, Bull. Seismol. Soc. Am. 75, 1135-1154.

Peyret, M., S. Dominguez, R. Cattin, J. Champenois, M. Leroy, and A. Zajac (2011). Present-day interseismic surface deformation along the Longitudinal Valley, eastern Taiwan, from a PS-InSAR analysis of the ERS satellite archives, J. Geophys. Res. 116, no. B03402, 21, doi 10.1029/ 2010JB007898.

Saastamoinen, I. I. (1972). Contribution to the theory of atmospheric refraction, Bull. Geod. 105, 279-298, doi 10.1007/BF02521844.

Schomaker, M. C., and R. M. Berry (1981). Geodetic leveling, in NOAA Manual NOS NGS 3, National Oceanic and Atmospheric Administration, Rockville, Maryland, $209 \mathrm{pp}$.

Shyu, J. B. H., L. H. Chung, Y. G. Chen, J. C. Lee, and K. Sieh (2007) Re-evaluation of the surface ruptures of the November 1951 earthquake series in eastern Taiwan, and its neotectonic implications, $J$ Asian Earth Sci. 31, 317-331.

Shyu, J. B. H., K. Sieh, and Y.-G. Chen (2005a). Tandem suturing and disarticulation of the Taiwan orogen revealed by its neotectonic elements, Earth Planet. Sci. Lett. 233, 167-177, doi 10.1016/ j.epsl.2005.01.018.

Shyu, J. B. H., K. Sieh, Y. G. Chen, and C. S. Liu (2005b). Neotectonic architecture of Taiwan and its implications for future large earthquakes, J. Geophys. Res. 110, no. B08402, 33, doi 10.1029/ 2004JB003251.

Shyu, J. B. H., K. Sieh, Y.-G. Chen, and L.-H. Chung (2006). Geomorphic analysis of the Central Range fault, the second major active structure of the Longitudinal Valley suture, eastern Taiwan, Geol. Soc. Am. Bull. 118, 1447-1462, doi 10.1130/B25905.1.

Shyu, J. B. H., K. Sieh, Y.-G. Chen, R. Y. Chuang, Y. Wang, and L.-H Chung (2008). Geomorphology of the southernmost Longitudinal Valley fault: implications for evolution of the active suture of eastern Taiwan, Tectonics 27, no. TC1019, 22, doi 10.1029/2006TC002060.

Shyu, J. B. H., K. Sieh, R. Y. Chuang, Y. Wang, L. H. Chung, and Y. G. ChenCaltech Ge122 Group(2002). River terrace deformation of the Luyeh River, eastern Taiwan, and the tectonic implications, in Annиa Meeting of the Geological Society of China, Tainan, Taiwan, 21-22 March 2002

Wells, D. L., and K. J. Coppersmith (1994). New empirical relationships among magnitude, rupture length, rupture width, rupture area, and surface displacement, Bull. Seismol. Soc. Am. 84, 974-1002.

Wu, Y. M., Y. G. Chen, T. C. Shin, H. Kuochen, C. S. Hou, J. C. Hu, C. H. Chang, C. F. Wu, and T. L. Teng (2006). Coseismic versus interseismic ground deformations, fault rupture inversion and segmentation revealed by $2003 M_{\mathrm{w}} 6.8$ Chengkung earthquake in eastern Taiwan, Geophys. Res. Lett. 33, no. 2, L02312, doi 10.1029/2005GL024711.
Yu, S.-B., and L.-C. Kuo (2001). Present-day crustal motion along the Longitudinal Valley fault, eastern Taiwan, Tectonophysics 333, 199-217, doi 10.1016/S0040-1951(00)00275-4.

Yu, S.-B., and C.-C. Liu (1989). Fault creep on the central segment of the Longitudinal Valley fault, eastern Taiwan, Proc. of the Geol. Soc. China 32, no. 3, 209-231.

Yu, S.-B., H.-Y. Chen, and L.-C. Kuo (1997). Velocity field of GPS stations in the Taiwan area, Tectonophysics 274, 41-59, doi 10.1016/S00401951(96)00297-1.

Yu, S.-B., G.-K. Yu, L.-C. Kuo, and C. Lee (1992). Crustal deformation in the southern Longitudinal Valley area, eastern Taiwan, J. Geol. Soc. China 35, no. 3, 219-230.

Department of Geological Sciences

Central Washington University

400 E. University Way

Ellensburg, Washington 98926

chuangyu@indiana.edu

(R.Y.C., M.M.M.)

Department of Geosciences

National Taiwan University

No. 1, Roosevelt Road, Section 4

Taipei, 10617, Taiwan

(Y.-G.C., L.-H.C.)

Institute of Earth Sciences

Academia Sinica

128, Academic Road, Section 2

Taipei, 115, Taiwan

(H.-Y.C., S.-B.Y.)

Division of Geophysical and Planetary Sciences

California Institute of Technology

1200 E. California Blvd

Pasadena, California 91125

(J.B.H.S.)

Department of Earth Sciences

Nanyang Technological University

Singapore

(C.M.R.)

Earth Observatory of Singapore

Nanyang Technological University

Singapore

(K.S.) 